DOI: http://dx.doi.org/10.33846/ghs5305

\title{
Pengaruh Edukasi Gizi Terhadap Pengetahuan dan Sikap Pasien Diabetes Mellitus Tipe II
}

\author{
Khartini Kaluku (koresponden) \\ (Jurusan Gizi, Poltekkes Kemenkes Maluku; kalukukhartini@gmail.com
}

\begin{abstract}
ABSTRAK
Diabetes melitus adalah penyakit metabolik yang ditandai dengan peningkatan kadar gula darah. Diabetes Melitus Tipe II sering disebut Diabetes Melitus yang tidak tergantung pada insulin. Sekitar 90-95\% dari kejadian diabetes di seluruh dunia adalah diabetes tipe II. Edukasi merupakan dasar utama pengobatan dan pencegahan DM yang sempurna. Salah satu langkah strategis untuk menambah pengetahuan dan menimbulkan motivasi kearah perbaikan kondisi status kesehatan keluarga adalah melakukan pemberdayaan keluarga atau masyarakat. Penelitian ini bertujuan untuk mengetahui pengaruh edukasi gizi terhadap pengetahuan dan sikap Pasien Diabetes Mellitus Tipe 2 di Puskesmas Air Besar Kota Ambon. Jenis penelitian ini adalah eksperimen murni dengan design penelitian pre test dan post test pada kelompok kontrol dan perlakuan. Dalam rancangan ini, pengelompokan anggota sampel dilakukan secara random. Penilaian dilakukan sebelum dan sesudah intervensi. Penelitian ini dilakukan di Puskesmas Air Besar, pada Bulan Agustus sampai dengan September 2015. Hasil penelitian diketahui terdapat perbedaan pengetahuan antara sebelum dan sesudah edukasi gizi dengan $p$ value $<0,05$, ada pengaruh edukasi terhadap sikap dalam hal ini kepatuhan diet dan kadar glukosa darah pasien Diabetes Millitus Tipe II dengan $p$ value < 0,05.
\end{abstract}

Kata kunci: edukasi; pengetahuan; sikap; diabetes mellitus tipe II

\section{PENDAHULUAN}

Diabetes melitus adalah penyakit metabolik yang ditandai dengan peningkatan kadar gula darah. Diabetes Melitus Tipe 2 sering pada usia dewasa dan disebabkan karena kurangnya produksi insulin atau tidak efektifnya penggunaan insulin oleh tubuh. Sekitar $90-95 \%$ dari kejadian diabetes di seluruh dunia adalah diabetes tipe II (Arora, 2008). Prevalensi global Jumlah kasus diabetes di antara remaja usia 10 tahun atau lebih tua, tingkat kasus baru adalah 18,6/100.000 setiap tahun untuk tipe 1 diabetes dan 8,5/100.000 untuk diabetes tipe 2 di Amerika (NIDDK, 2011). Berdasarkan kutipan Ucik (2009) yaitu diantara tipe DM yang ada, DM tipe II adalah jenis yang paling banyak ditemukan (lebih dari 90\%). Kekerapan DM tipe II di Indonesia berkisar antara 1,5-2,3\% kurang lebih 15 tahun yang lalu, tetapi pada tahun 2001 survei terakhir di Jakarta (Depok) menunjukkan kenaikan yang sangat nyata yaitu menjadi 12,8\% (Suyono, 2011). Menurut Sujudi (2003), sekitar 2,5 juta jiwa atau 1,3\% dari penduduk Indonesia setiap tahun meninggal dunia karena komplikasi DM Tipe 2. DM Tipe 2 merupakan penyakit serius, mahal, dan semakin umum (Jeffry,2005).

Berdasarkan hasil Riskesdas 2013, Prevalensi penyakit DM di Indonesia berdasarkan diagnosis oleh tenaga kesehatan adalah 1,5\% sedangkan prevalensi DM (D/G) sebesar 2,1\%. Data ini menunjukkan cakupan diagnosis DM oleh tenaga kesehatan mencapai 63,6\%, lebih tinggi dibandingkan cakupan penyakit asma maupun penyakit jantung. Kasus DM di Propinsi Maluku berdasarkan diagnosis oleh tenaga kesehatan menurut umur (55-64 tahun) adalah 4,8\% sedangkan prevalensi DM (D/G) sebesar 5,5\%. Data terakhir Pasien Diabetes Melitus di Puskesmas Air Besar sampai dengan September 2014 sebanyak 218 pasien.Di Puskesmas ini melakukan Health Education mengenai penggunaan obat tetapi tidak dilakukan edukasi seperti pengaturan diet untuk penderita DM.

Diabetes Melitus jika tidak dikelola dengan baik akan mengakibatkan terjadinya berbagai komplikasi menahun seperti penyakit serebro-vaskuler, penyakit jantung koroner, penyakit pembuluh darah tungkai, komplikasi pada mata, ginjal dan syaraf (Soegondo dkk, 2007). Masalah kesehatan akibat Diabetes Melitus dapat menurunkan kualitas hidup. Dalam pengelolaan diabetes, langkah pertama yang harus dilakukan adalah pengelolaan secara non farmakologis yaitu perencanaan diet, aktivitas fisik, dan penyuluhan. Jika pengendalian kadar glukosa dengan cara ini tidak tercapai, maka langkah selanjutnya adalah pengelolaan farmakologis atau penggunaan obat (Dalimarta, 2005). Sukardji (2007) menjelaskan suatu model terapi gizi medis yang direkomendasikan oleh American Diabetes Association (ADA). Dalam model tersebut diperlukan pendekatan tim yang terdiri dari dokter, dietisien, perawat dan petugas kesehatan lain serta pasien itu sendiri untuk meningkatkan kemampuan setiap pasien dalam mencapai kontrol metabolic yang baik. Tidak hanyaitu, diperlukan 
suatu metode edukasi yang lebih efektif bagi penderita diabetes, yaitu suatu metode pendekatan yang melibatkan keluarga dalam pengelolaan penderita diabetes mellitus (Soegondo, 2007).

Edukasi merupakan dasar utama untuk pengobatan dan pencegahan Diabetes Melitus yang sempurna. Pengetahuan yang minim tentang Diabetes Melitus akan lebih cepat menjurus kearah timbulnya komplikasi dan hal ini akan merupakan beban bagi keluarga dan masyarakat. Pengetahuan gizi merupakan faktor yang sangat penting dalam menentukan sikap dan perilaku seseorang terhadap makanan.Selain itu pengetahuan gizi merupakan peranan penting untuk dapat membuat manusia hidup sehat sejahtera dan berkualitas. Gizi mempunyai hubungan langsung dengan tingkat konsumsi tetapi secara langsung mencerminkan tingkat pengetahuan (Rusimah,2011). Salah satu langkah yang cukup strategis untuk menambah pengetahuan dan menimbulkan motivasi kearah perbaikan kondisi status kesehatan keluarga adalah melakukan pemberdayaan keluarga atau masyarakat. Bentuk kegiatan pemberdayaan keluarga antara lain dilakukan melalui edukasi gizi yang bertujuan untuk meningkatkan kemampuan keluarga dalam mencegah dan mengatasi sendiri masalah gizi anggota keluarganya. Edukasi gizi di bidang gizi dan kesehatan adalah salah satu bentuk penyuluhan yang bersifat intensif lewat tatap muka harian.Edukasi dilakukan dengan menggunakan Booklet kepada pasien dan keluarga.

Metode edukasi gizi dinilai lebih efektif dibandingkan metode penyuluhan konvensional. Hal ini sesuai dengan hasil penelitian yang dilakukan oleh Amir (2008) yang menyimpulkan bahwa edukasi/penyuluhan dengan metode edukasi gizi mempunyai hubungan yang signifikan dengan peningkatan pengetahuan ibu, pola asuh anak, tingkat konsumsi dan perubahan status gizi balita gizi buruk dibanding metode penyuluhan konvensional yang dilakukan setiap bulan di Posyandu. Oleh karena itu peneliti tertarik untuk mengadopsi metode edukasi gizi yang dilakukan terhadap keluarga balita gizi buruk untuk diterapkan terhadap penderita Diabetes Melitus Tipe 2.

\section{METODE}

Penelitian ini merupakan penelitian eksperimen dengan design penelitian pre test dan post test pada kelompok kontrol dan perlakuan. Sampel semua pasien DM tipe II yang berkunjung ke Puskesmas Air Besar Kota Ambon pada bulan Agustus 2015. Dari 48 Pasien, hanya 40 orang yang bersedia dan memenuhi syarat untuk dijadikan sampel, kemudian dilakukan randomisasi. Pasien urutan nomor ganjil sebagai kelompok perlakuan, dan nomor genap sebagai kelompok kontrol. Penelitian dilaksanakan di Puskesmas Air Besar Kota Ambon. Sampel dalam penelitian ini akan menggunakan kelompok intervensi yang diberi edukasi gizi dan sampel kelompok kontrol tanpa diberi edukasi gizi.

Tahapan penelitian ini dimulai dari persiapan meliputi studi literature melalui review kepustakaan dan studi jurnal penelitian yang berkaitan dengan permasalahan penelitian, studi pendahuluan Ke Dinas Kesehatan Kota Ambon dengan melakukan pengumpulan data sekunder pra penelitian, pengajuan proposal penelitian dan seminar proposal pada tanggal 24 Nopember 2014 , mengajukan izin penelitian kepada Walikota Ambon, mengajukan ethical clearance, rekrut tenaga pengumpul data (enumerator), menyiapkan instrument penelitian, melakukan pelatihan enumerator, melakukan screening penderita DM yang berkunjung ke Puskesmas dan selanjutnya menentukan kelompok intervensi dan kontrol. Kemudian tahap pelaksanaan meliputi pengumpulan data dan pengolahan data serta penyusunan laporan hasil penelitian meliputi analisis, interpretasi data, pembahasan, kesimpulan dan saran.

Pasien DM Tipe II yang memenuhi kriteria sampel, dimintai persetujuan (informed consent) untuk bersedia menjadi sampel sampai penelitian selesai. Kemudian dilakukan wawancara untuk pengambilan data Identitas pasien, pengetahuan tentang DM menggunakan kuesioner, recall 24 jam menggunakan form recall, pengukuran antropometri (Berat Badan dan Tinggi Badan), tes kadar glukosa darah menggunakan gluco Dr enumerator terlatih.

Intervensi edukasi gizi diawali dengan screening untuk mendapatkan sasaran intervensi. Setelah sasaran terdaftar selanjutnya dirandom dengan cara undi untuk menentukan kelompok intervensi dan kelompok kontrol dibuatkan jadwal kunjungan yang disepakati oleh sasaran. Selanjutnya dilakukan persiapan kelengkapan instrumen penelitian. Setelah itu sampel kelompok intervensi dikunjungi untuk diedukasi terkait pengelolaan diabetes melitus. Sebelum Intervensi, terlebih dahulu dilakukan pre test, recall 24 jam, dan pemeriksaan kadar glukosa darah. Pada Sesi ini dilakukan edukasi oleh peneliti dibantu oleh Tenaga Gizi Puskesmas (TGP) agar melibatkan keluarga menerapkan praktek asuhan gizi bagi pasien yaitu pengelolaan makanan yang tepat bagi penyandang DM sesuai pedoman 3 j yaitu tepat jenis, tepat jumlah dan tepat jadwal. Sedangkan pada kelompok kontrol hanya dilakukan pre test, recall 24 jam dan pemeriksaan kadar glukosa 
darah. Kegiatan monitoring dan evaluasi penerapan instruksi selama edukasi dilakukan sebagai tahap akhir penelitian sekaligus melaksanakan Post Test.

Pengumpulan data dilakukan dengan cara wawancara dan observasi. Analisis data untuk menguji hipotesis penelitian menggunakan Uji $t$ berpasangan untuk melihat perbedaan pengetahuan sebelum dan sesudah edukasi gizi pada kelompok intervensi dan kontrol dan Uji chi-square untuk melihat pengaruh edukasi gizi terhadap sikap yaitu kepatuhan diet, kepatuhan minum obat, aktifitas fisik dan kadar glukosa darah antara kelompok intervensi dengan kontrol dengan tingkat kemaknaan yang digunakan adalah $\alpha=0,05$.

\section{HASIL}

\section{Karakteristik Sampel Penelitian}

Tabel 1. Karakteristik Sampel Penelitian Pada Kelompok Perlakuan Dan Kontrol

\begin{tabular}{|c|c|c|c|c|}
\hline \multirow[b]{2}{*}{ Variabel } & \multicolumn{4}{|c|}{ Kelompok } \\
\hline & $\begin{array}{c}\text { Perlakuan } \\
(\mathrm{n}=20)\end{array}$ & $\%$ & $\begin{array}{l}\text { Kontrol } \\
(n=20)\end{array}$ & $\%$ \\
\hline \multicolumn{5}{|l|}{ Jenis Kelamin } \\
\hline Laki-laki & 4 & 20 & 4 & 20 \\
\hline Perempuan & 16 & 80 & 16 & 80 \\
\hline \multicolumn{5}{|l|}{ Umur } \\
\hline$>40$ Tahun & 17 & 85 & 17 & 85 \\
\hline$\leq 40$ Tahun & 3 & 15 & 3 & 15 \\
\hline \multicolumn{5}{|l|}{ Pendidikan } \\
\hline SD & 4 & 20 & 2 & 10 \\
\hline SMP & 5 & 25 & 6 & 30 \\
\hline SMA & 8 & 40 & 8 & 40 \\
\hline Diploma/Sarjana & 3 & 15 & 4 & 20 \\
\hline \multicolumn{5}{|l|}{ Pekerjaan } \\
\hline IRT & 9 & 45 & 10 & 50 \\
\hline PNS & 4 & 20 & 5 & 25 \\
\hline Peg. Swasta & 2 & 10 & 0 & 0 \\
\hline Pedagang & 4 & 20 & 2 & 10 \\
\hline Buruh & 1 & 5 & 1 & 5 \\
\hline Lain-lain & 0 & 0 & 2 & 10 \\
\hline \multicolumn{5}{|l|}{ Lama Sakit } \\
\hline$<5$ Tahun & 15 & 75 & 11 & 55 \\
\hline$>5$ Tahun & 5 & 25 & 9 & 45 \\
\hline \multicolumn{5}{|l|}{ Status Gizi } \\
\hline Kurus & 1 & 5 & 2 & 10 \\
\hline Normal & 8 & 40 & 8 & 40 \\
\hline Gemuk & 11 & 55 & 10 & 50 \\
\hline
\end{tabular}


Data karakteristik sampel penelitian terdiri dari jenis kelamin, umur, pendidikan, pekerjaan, lama sakit dan status gizi. Jenis kelamin terbanyak adalah perempuan sebanyak 80 . Umur terbanyak adalah > 40 tahun, sebanyak $85 \%$. Pendidikan terbanyak adalah SMA, sebanyak $40 \%$. Jenis pekerjaan terbanyak adalah lbu Rumah Tangga (IRT), sebanyak 45\% pada kelompok perlakuan dan $50 \%$ pada kelompok kontrol. Rata-rata lama sakit DM adalah $>5$ tahun, $75 \%$ untuk kelompok perlakuan dan $55 \%$ pada kelompok kontrol. Status gizi mayoritas berkategori gemuk seperti tercantum pada tabel 1 .

\section{Pengetahuan}

Pengetahuan sampel diukur sebelum dan sesudah diberi edukasi gizi. Hasil akhir dinyatakan dengan skor dari setiap jawaban pertanyaan. Pada kelompok perlakuan rata-rata skor pengetahuan sebelum diberi edukasi gizi adalah 67.50 dengan standar deviasi 19.55 dan pada akhir penelitian setelah diberi edukasi gizi rata-rata skor pengetahuan adalah 71.85 dengan standar deviasi 16.41 . Pada kelompok kontrol rata-rata skor pengetahuan sampel pada awal penelitian adalah 63.95 dengan standar deviasi 16.70 dan pada akhir penelitian rata-rata skor pengetahuan ibu adalah 69.60 dengan standar deviasi 15.82. Untuk lebih jelasnya pengetahuan ibu dapat dilihat pada tabel 2.

Tabel 2. Rata-rata Pengetahuan Ibu Pada Kelompok Perlakuan dan Kontrol

\begin{tabular}{|c|c|c|}
\hline \multirow{2}{*}{ Pengetahuan Ibu } & \multicolumn{2}{|c|}{ Kelompok } \\
\cline { 2 - 3 } & Perlakuan & Kontrol \\
\hline Sebelum & $67.50 \pm 19.55$ & $63.95 \pm 16.70$ \\
\hline Sesudah & $71.85 \pm 16.41$ & $69.60 \pm 15.82$ \\
\hline
\end{tabular}

\section{Sikap Kepatuhan Diet}

Tabel 3. Distribusi Sampel Berdasarkan Sikap Kepatuhan Diet Pada Kelompok Perlakuan Dan Kontrol

\begin{tabular}{|c|c|c|c|c|}
\hline \multirow{2}{*}{ Kepatuhan Diet } & \multicolumn{4}{|c|}{ Kelompok } \\
\cline { 2 - 5 } & \multicolumn{2}{|c|}{ Perlakuan } & $\mathrm{n}(20)$ & $\%$ \\
\cline { 2 - 5 } & $\mathrm{n}(20)$ & $\%$ & 8 & 40 \\
Energi & 18 & 90 & 12 & 60 \\
Patuh & 2 & 10 & 13 & 65 \\
Tidak Patuh & 20 & 100 & 7 & 35 \\
\hline Karbohidrat & 0 & 0 & 6 & 30 \\
Patuh & 10 & 50 & 14 & 70 \\
Tidak Patuh & 10 & 50 & 2 & 10 \\
\hline Protein & 2 & 10 & 18 & 90 \\
Patuh & 18 & 90 & & \\
Tidak Patuh & & & & \\
\hline Lemak & & & & \\
Patuh & & & & \\
Tidak Patuh & & & & \\
\hline
\end{tabular}


Kepatuhan diet dinilai berdasarkan asupan energi, karbohidrat, protein dan lemak. Hasil penelitian tentang kepatuhan diet pada akhir penelitian menunjukkan presentasi terbesar kepatuhan dietberdasarkan asupan energy pada kelompok perlakuan adalah kategori patuh $(90 \%)$, sedangkan pada kelompok kontrol presentasi terbesar adalah tidak patuh (60\%). Kepatuhan diet berdasarkan asupan karbohidrat terbanyak adalah kategori patuh, yaitu sebesar $100 \%$ pada kelompok perlakuan dan $65 \%$ pada kelompok kontrol. Kepatuhan diet berdasarkan asupan protein pada kelompok perlakuan kategori patuh $50 \%$ dan tidak patuh $50 \%$. Sedangkan pada kelompok kontrol presentasi terbanyak adalah kategori tidak patuh. Kepatuhan diet berdasarkan asupan lemak terbanyak adalah kategori patuh, yaitu sebesar $90 \%$ pada kelompok perlakuan dan pada kelompok kontrol terlihat pada tabel 3 berikut:

\section{Analisis Bivariat}

Analisis bivariat dilakukan terhadap data perubahan pengetahuan sebelum dan sesudah edukasi gizi pada kelompok perlakuan, data kepatuhan diet antara kelompok perlakuan dengan kelompok kontrol dan data kadar glukosa darah antara kelompok perlakuan dengan kelompok kontrol.

\section{Pengaruh Edukasi Gizi Terhadap pengetahuan pasien Diabetes Melitus Tipe 2}

Analisa bivariat pengetahuan dilakukan pada kelompok perlakuan dengan melihat besar perbedaan pengetahuan sebelum dan sesudah edukasi dengan menggunakan uji statistik paired $t$ test. Rata-rata skor pengetahuan sebelum diberi edukasi gizi adalah 67.50 dengan standar deviasi 19.55 dan pada akhir penelitian setelah diberi edukasi gizi rata-rata skor pengetahuan adalah 71.85 dengan standar deviasi 16.41. Hasil analisis menunjukkan $p$ value $=0.00$, lebih kecil dibandingkan dengan $\alpha(0.05)$, menunjukkan ada perbedaan pengetahuan sebelum dengan sesudah edukasi gizi. Hasil dapat dilihat pada tabel 5 berikut:

Tabel 5. Rata-rata Perbedaan Pengetahuan Sampel Sebelum Dan Sesudah Edukasi gizi Pada Kelompok Perlakuan

\begin{tabular}{|c|c|c|}
\hline Pengetahuan & Nilai Rata-Rata & P value \\
\hline Sebelum Perlakuan & $67.50 \pm 19.55$ & \multirow{2}{*}{0.00} \\
\hline Sesudah Perlakuan & $71.85 \pm 16.41$ & \\
\hline
\end{tabular}

\section{Pengaruh edukasi gizi terhadap Sikap kepatuhan diet pasien Diabetes Millitus Tipe II}

Hasil Penelitian menunjukkan kepatuhan diet berdasarkan asupan energy presentasi terbanyak patuh pada kelompok perlakuan $(69.2 \%)$, sedangkan kategori tidak patuh terbanyak pada kelompok kontrol (85.7\%). Untuk mengetahui pengaruh edukasi gizi terhadap kepatuhan diet dilakukan uji statistik chi-square, dengan hasil uji $p$ value $=0.001$, menunjukkan ada pengaruh edukasi gizi terhadap kepatuhan diet energi. Kepatuhan diet berdasarkan asupan karbohidrat presentasi terbanyak kategori patuh terdapat pada kelompok perlakuan $(60.6 \%)$, sedangkan kategori tidak patuh semuanya terdapat pada kelompok kontrol (100\%). Untuk mengetahui pengaruh edukasi gizi terhadap kepatuhan diet dilakukan uji statistik chi-square, dengan hasil uji $p$ value $=0.008$, menunjukkan ada pengaruh edukasi gizi terhadap kepatuhan diet karbohidrat. Kepatuhan diet berdasarkan asupan protein presentasi terbanyak kategori patuh terdapat pada kelompok perlakuan $(62.5 \%)$, sedangkan kategori tidak patuh presentasi terbanyak pada kelompok kontrol (58.3\%). Untuk mengetahui pengaruh edukasi gizi terhadap kepatuhan diet dilakukan uji statistik chi-square, dengan hasil uji $p$ value $=0.197$, menunjukkan tidak ada pengaruh edukasi gizi terhadap kepatuhan diet protein. Kepatuhan diet berdasarkan asupan lemak kategori patuh dan tidak patuh mempunyai presentasi yang sama banyak, baik pada kelompok perlakuan maupun kelompok kontrol, masingmasing 50\%. Untuk mengetahui pengaruh edukasi gizi terhadap kepatuhan diet dilakukan uji statistik chi-square, dengan hasil uji $p$ value $=1.000$, menunjukkan tidak ada pengaruh edukasi gizi terhadap kepatuhan diet lemak. Untuk lebih jelasnya data dapat dilihat pada tabel 6. 
Tabel 6. Distribusi Kepatuhan Diet Berdasarkan Edukasi gizi Pada Pasien Diabetes Millitus Tipe II

\begin{tabular}{|c|c|c|c|c|c|c|}
\hline \multirow{3}{*}{ Kepatuhan Diet } & \multicolumn{4}{|c|}{ Kelompok } & \multirow{3}{*}{ Total } & \multirow{3}{*}{$P$ value } \\
\hline & \multicolumn{2}{|c|}{ Perlakuan } & \multicolumn{2}{|c|}{ Kontrol } & & \\
\hline & n (20) & $\%$ & n (20) & $\%$ & & \\
\hline Energi & & & & & & \\
\hline Patuh & 18 & 69.2 & 8 & 30.8 & $26(100 \%)$ & 0.001 \\
\hline Tidak Patuh & 2 & 14.3 & 12 & 85.7 & $14(100 \%)$ & \\
\hline Karbohidrat & & & & & & \\
\hline Patuh & 20 & 60.6 & 13 & 39.4 & $33(100 \%)$ & 0.008 \\
\hline Tidak Patuh & 0 & 0 & 7 & 100 & 7 (100\%) & \\
\hline Protein & & & & & & \\
\hline Patuh & 10 & 62.5 & 6 & 37.5 & $16(100 \%)$ & 0.197 \\
\hline Tidak Patuh & 10 & 41.7 & 14 & 58.3 & $24(100 \%)$ & \\
\hline Lemak & & & & & & \\
\hline Patuh & 2 & 50 & 2 & 50 & $4(100 \%)$ & 1.000 \\
\hline Tidak Patuh & 18 & 50 & 18 & 50 & $36(100 \%)$ & \\
\hline
\end{tabular}

\section{PEMBAHASAN}

\section{Perbedaan Pengetahuan Pasien Diabetes Melitus Tipe 2}

Hasil penelitian menunjukkan ada perbedaan pengetahuan sebelum dengan sesudah edukasi gizi. Hal ini sejalan denan penelitian yang dilakukan oleh Sukraniti (2010) tentang pengaruh konseling gizi terhadap perubahan kadar gula darah berdasarkan pengetahuan dan kepatuhan diet penderita diabetes mellitus, diketahui bahwa peningkatan pengetahuan tentang diabetes mellitus bagi penderita DM melalui konseling sangat efektif. Edukasi gizi asuhan gizi bagi penyandang DM adalah kegiatan edukasi gizi tentang tata cara pengelolaan makanan yang tepat bagi penyandang DM sesuai pedoman $3 \mathrm{~J}$ yaitu tepat Jenis, tepat Jumlah dan tepat Jadwal dilakukan terhadap setiap individu atau kelompok dalam wilayah binaan yang telah ditentukan agar tercapai kontrol metabolik yang baik (Depkes, 2007).

Secara umum program edukasi gizi gizi bertujuan untuk meningkatkan status gizi keluarga melalui kegiatan edukasi gizi. Adapun yang menjadi tujuan khusus program edukasi gizi gizi bagi penyandang DM adalah mengontrol kadar glukosa darah penyandang DM; meningkatkan pengetahuan gizi keluarga; meningkatkan kepatuhan diet, aktifitas fisik dan minum obat bagi penyandang DM; dan meningkatkan keluarga sadar gizi (Depkes, 2007).

Dengan pemberian edukasi model edukasi gizi dinilai cukup efektif karena responden selalu dimonitoring pola makan yang dinilai dari ketepatan jumlah, jenis dan jadwal. Hal ini juga dibantu oleh peran serta keluarga yang senantiasa memantau perkembangan responden.

Hasil penelitian ini sejalan pula dengan yang dikemukakan Esti Setiyani yang menyatakan bahwa penyuluhan merupakan salah satu faktor terpenting dalam penanganan diabetes Mellitus khususnya dalam penerapan diit yang baik dimana dalam penyuluhan ini dapat diberikan pengetahuan dan ketrampilan dalam menerapkan diitnya dengan baik. Menurut Suyono (2005), pengetahuan tersebut akan menjadi titik tolak perubahan sikap dan gaya hidup mereka. Pada akhirnya yang menjadi tujuan penyuluhan adalah perubahan perilaku penyandang diabetes dan meningkatnya kepatuhan yang selanjutnya meningkatkan kualitas hidup (Wakhidiyah dkk, 2010).

Dari hasil penelitian pada kelompok kontrol juga terjadi peningkatan rata-rata pengetahuan, hal ini disebabkan karena pengetahuan tidak hanya diperoleh dibangku pendidikan tapi juga dari pengalaman langsung maupun tidak langsung. Secara teoritis, pengetahuan merupakan domain yang sangat penting untuk terbentuknya perilaku seseorang, tapi bukan faktor yang cukup kuat utuk 
merubah perilaku sehat. Perlu adanya niat yang cukup sehingga seseorang berbuat sesuai dengan pengetahuannya (Isniati,2003).

Pengetahuan merupakan pencapaian pada status gizi yang baik dan sangat penting artinya bagi kesehatan dan kesejahteraan bagi setiap orang. Untuk memenuhi kebutuhan gizinya setiap individu memiliki pola makanan yang mengandung zat gizi yang dapat digunakan oleh tubuh. Pengetahuan gizi dapat memegang peranan penting terhadap tata cara penggunaan pangan dengan baik sehingga akan mencapai kebutuhan gizi yang seimbang. Tingkat pengetahuan gizi akan dapat menentukan perilaku seseorang untuk memperbaiki pola konsumsi makanan yang umumnya dipandang lebih baik dan dapat diberikan sedini mungkin (Almatsier 2003 dikutip oleh Kristianti 2009).

Rendahnya tingkat pengetahuan gizi akan dapat mengakibatkan sikap acuh tak acuh terhadap penggunaan bahan makanan tertentu, walaupun bahan makanan tersebut cukup tersedia dan mengandung zat gizi.

Pengetahuan penderita mengenai diabetes Mellitus merupakan sarana yang membantu penderita menjalankan penanganan diabetes selama hidupnya. Dengan demikian semakin banyak dan semakin baik penderita mengerti mengenai penyakitnya, maka semakin mengerti bagaimana harus mengubah perilakunya dan mengapa hal itu di perlukan (Waspadji, 2009).

Tingkat pengetahuan yang rendah akan dapat mempengaruhi pola makan yang salah sehingga menyebabkan kegemukan, yang akhirnya mengakibatkan kenaikan kadar glukosa darah. Diperkirakan sebesar $80-85 \%$ penderita DM tipe 2 mengidap kegemukan. Hal ini terjadi karena tingginya asupan karbohidrat dan rendahnya asupan serat. Salah satu upaya pencegahan DM adalah dengan perbaikan pola makan melalui pemilihan makanan yang tepat. Semakin rendah penyerapan karbohidrat, semakin rendah kadar glukosa darah. Kandungan serat yang tinggi dalam makanan akan mempunyai indeks glikemik yang rendah sehingga dapat memperpanjang pengosongan lambung yang dapat menurunkan sekresi insulin dan kolesterol total dalam tubuh (Witasari, 2009).

Menurut Azwar dan Notoatmodjo, pengetahuan dan sikap tidak berhubungan secara langsung dengan perilaku kesehatan tetapi masih ada faktor-faktor penganggu yang mempengaruhi perilaku kesehatan antara lain sistem kepribadian, pengalaman, adat istiadat, yang dipegang oleh individu tersebut serta adanya faktor pendukung atau kondisi yang memungkinkan , antara lain fasilitas yang memadai (Jazilah, 2003).

Dengan semakin baik dan luasnya pengetahuan responden maka diharapkan semakin baik pula pengetahuannya terhadap gizi dan kesehatan, khususnya dalam hal bahan makanan yang baik untuk dikonsumsi. Hal ini selaras dengan yang dikatakan Sediaoetama (1987), bahwa semakin banyak pengetahuan gizinya, semakin diperhitungkan jenis dan kuantum makananan yang dipilih untuk dikonsumsinya. Pemahaman awam yang tidak mempunyai cukup pengetahuan gizi, akan memilih makanan yang paling menarik panca indera, dan tidak mengadakan pilihan berdasarkan nilai gizi makanan. Sebaliknya mereka yang semakin banyak pengetahuan gizinya, lebih banyak mempergunakan pertimbangan rasional dan pengetahuan tentang nilai gizi makanan tersebut.

\section{Pengaruh Edukasi gizi Terhadap Sikap Kepatuhan Diet Pasien Diabetes Millitus Tipe II}

Dari hasil penelitian diketahui ada pengaruh edukasi gizi terhadap kepatuhan diet energi dan karbohidrat. Hal ini sejalan dengan penelitian Chabchoub, Blouza S, et all,( 2000) menunjukkan bahwa korelasi negatif yang signifikan antara asupan energi total dan jumlah karbohidrat $(r=-0,46, p$ $<0,01)$ setelah dilakukan edukasi gizi. Dan menurut Husein (2010) menunjukkan tidak ada beda ratarata yang signifikan pada intake energi dan zat gizi responden $(\rho<0.05)$, rata-rata intake energi dan zat gizi responden pada hari ke 14 cenderung meningkat namun tidak melebihi batas normal anjuran.

Sedangkan hasil penelitian menunjukkan tidak ada pengaruh edukasi gizi terhadap kepatuhan asupan protein dan lemak. Ketidakpatuhan menjalankan diet dapat disebabkan karena beberapa alasan yaitu tidak dapat mengendalikan nafsu makan, merasa telah terkonttrol gula darahnya karena pemberian obat diabetes dari dokter, sehingga merasa tidak perlu menjalankan diet dengan baik. Selain itu pendapat kurang mendukung untuk memenuhi konsumsi bahan makanan dengan kualitas dan kuantitas yang baik dan juga alasan kesibukan bekerja, sehingga tidak dapat mengatur waktu yang tepat untuk makan sesuai jadwal, jumlah maupun jenis dari bahan makanan yang boleh dan tidak boleh untuk dikonsumsi (Abduracchim, 2008).

Menurut Satot dkk (1998) dikatakan bahwa makan dalam jumlah banyak dan tidak seimbang menyebabkan keadaan gizi lebih yang selanjutnya membawa resiko masalah kesehatan terutama penyakit degeneratif. Uji toleransi glukosa penderita kelebihan berat badan hampir selalu menunjukkan ketidaknormalan yang merupakan indikator resistensi insulin pada Diabetes Mellitus (Moda dkk, 2012). 
Kemampuan penderita DM untuk mengontrol kehidupannya dapat mempengaruhi tingkat kepatuhan. Seseorang yang berorientasi pada kesehatan cenderung mengadopsi semua kebiasaan yang dapat meningkatkan kesehatan dan menerima regimen yang akan memulihkan kesehatannya. Orang yang melihat penyakit sebagai kelemahan akan menyangkal penyakit atau hadirnya penyakit itu. Pengingkaran ini dapat mempengaruhi terjadinya ketidakpatuhan. Ketidakpatuhan merupakan salah satu masalah yang berat dalam dunia medis, dan oleh karena itu sejak tahun 1960-an sudah mulai diteliti di negara-negara industri. Secara umum, ketidakpatuhan meningkatkan risiko berkembangnya masalah kesehatan dan dapat berakibat memperpanjang atau memperburuk penyakit yang sedang diderita (Smet, 1994).

Kepatuhan diet sangat tergantung dari kemauan serta minat responden dan peran serta keluarga dalam pemilihan bahan makanan dan pengolahan hingga tahap penyajian untuk menakar jumlah makanan yang akan dikonsumsi oleh responden, sehingga dalam mengatur diet masih ada sebagian responden yang belum mematuhi diet yang diberikan. Adapun yang menjalani diet hanya pada saat sebelum peneliti datang untuk memeriksakan kepatuhan diet dan kadar gula darah responden. Sehingga pada saat dilakukan post test kepatuhan dietnya dilakukan analisis patuh tetapi saat pengukuran kadar gula didapatkan kadar gulanya tidak terkendali.

Salah satu pilar utama pengelolaan diabetes adalah diet. Meskipun sudah sedemikian majunya riset di bidang pengobatan diabetes dengan ditemukannya berbagai jenis insulin dan obat oral yang mutakhir, diit masih tetap merupakan pengobatan yang utama pada penatalaksanaan diabetes, terutama diabetes mellitus tipe II (Waspadji, 2004).

Menurut Feuer Stein et al (1998) dalam Niven (2002) ada beberapa faktor yang mempengaruhi kepatuhan responden termasuk kepatuhan dalam melaksanakan program diet pada responden Diabetes Mellitus yaitu pemahaman tentang instruksi, kualitas interaksi, dukungan sosial keluarga, serta keyakinan, sikap dan kepribadian responden. Dari ke-4 faktor tersebut, dukungan sosial keluarga merupakan salah satu faktor yang tidak dapat diabaikan begitu saja, karena dukungan sosial keluarga merupakan salah satu dari faktor yang memiliki kontribusi yang cukup berarti dan sebagai faktor penguat yang mempengaruhi kepatuhan responden Diabetes Mellitus. Diabetes merupakan penyakit kronis yang dapat hilang timbul atau dapat kambuh kapan saja jika responden tidak mengikuti program yang telah ditetapkan oleh petugas kesehatan (Lestari, 2010).

Penyandang diabetes mempunyai resiko tinggi untuk mendapatkan penyakit jantung dan pembuluh darah, oleh karena itu lemak dan kolesterol dalam makanan perlu dibatasi. Untuk itu makanan janganlah terlalu banyak digoreng, bila diinginkan mungkin tidak lebih dari satu lauk saja yang digoreng pada setiap kali makan untuk mereka yang tidak gemuk. Selebihnya dapat dimasak dengan sedikit minyak seperti dipanggang, dikukus, direbus atau dibakar. Kebiasaan mengkonsumsi lemak hewani berlebihan dapat menyebabkan penyempitan pembuluh darah arteri dan penyakit jantung koroner. Membiasakan makan ikan dapat mengurangi resiko menderita penyakit jantung koroner karena ikan mengandung asam lemak omega 3 (Soegondo dkk, 2011).

\section{KESIMPULAN}

Edukasi gizi adalah salah satu pilar utama penanganan Diabetes Mellitus yang dibuktikan melalui penelitian ini bahwa ada pengaruh edukasi gizi terhadap pengetahuan dan sikap pasien Diabetes Melitus Tipe 2.

\section{DAFTAR PUSTAKA}

1. Abduracchim, Rijanti, dkk, 2008. Hubungan Tingkat Kepatuhan Diet Dengan Gula Reduksi Urin Dan Indeks Massa Tubuh Pada Diabetesi Yang Berobat Jalan Di Poliklinik Gizi RSUD Ulin Banjarmasin. Jurusan Gizi Politeknik Kesehatan Banjarmasin, Instalasi Gizi RSUD Ulin Banjarmasin. Jurnal Kalimatan Scientiae No.71 Th XXVI Vol. April 2008 Hal: 24.

2. Almatsier, Sunita, dkk., 2006. .Penuntun Diet Edisi Baru. PT Gramedia Pustaka Utama: Jakarta.

3. Arora, Dr. Anjali, 2008. 5 Langkah Mencegah dan Mengobati Diabetes. Jakarta: PT Bhuana IImu Populer Kelompok Gramedia.

4. Amir A, 2008.Pengaruh Penyuluhan Model Edukasi gizi Terhadap. Perubahan Status Gizi Anak Usia 6-24 Bulan. Thesis Pascasarjana Universitas Diponegoro: Semarang.

5. Chabchoub, Blouza S, et all, 2000. The Effect Of Nutritional Education On The Food Intake Regulation Of The Young Diabetic,. Institut National de Nutrition, Service A, Tunis. Tunis Med. Jurnal NCBI. Oktober 2000; 78 (10): 595-9. 
6. Dalimartha S, 2005. Ramuan Tradisionanl Untuk Pengobatan Diabetes Mellitus. Jakarta:Penebar Swadaya

7. Isniati, 2003, Hubungan Tingkat Pengetahuan Penderita Diabetes Mellitus Dengan Keterkendalian Gula Darah Di Poliklinik Rs Perjan Dr. M. Djamil Padang Tahun.Jurnal Kesehatan Masyarakat, September 2007, I (2).

8. Istiyanto, 2011.Transparansi Komunikasi Kesehatan [online] (diupload pada tanggal 2 Februari 2008). http://sbektiistiyanto.files.wordpress.com/2008/02/ transparansi-komkes.ppt [di akses tanggal 20 Desember 2014].

9. Jazilah, dkk, 2003. Hubungan Tingkat Pengetahuan, Sikap dan Praktek (PSP) Penderita Diabetes Melitus dengan Kendali Kadar Glukosa Darah.Program Studi IImu Kesehatan Masyarakat. Program Pascasarjana Universitas Gadjah Mada. Jurnal Sains Kesehatan, 16 (3) September 2003 Hal: 419

10. Jeffrey M. and Curtis, MD, MPH., 2005.Preventing Type 2 Diabetes Mellitus. Journal :J Am Fam Med Dewan Januari 1, 2005vol.18no.137-43 Hal: 7. Phoenix India Medical Center, India Pelayanan Kesehatan, 4212 N. 16th Street, Phoenix, AZ 85016.

11. Kristianti Nanik., 2009. Hubungan Pengetahuan Gizi Dan Frekuensi Konsumsi Fast Food Dengan Status Gizi Siswa Sma Negeri 4 Surakarta. KTI D3. Fakultas IImu Kesehatan, Universitas Muhammadiyah Surakarta, Surakarta.

12. Lestari, Lingar Angina, dkk, 2010. Hubungan Antara Dukungan Sosial Keluarga Dengan Kepatuhan Pasien Diabetes Mellitus Dalam Melaksanakan Program Diet Di Poli Penyakit Dalam Rsud Cibabat Cimahi. Edisi Khusus Hari Kesehatan Nasional, November 2010 ISSN: 2086-3098. Jurnal Penelitian Kesehatan Suara Forikes Edisi November 19 November 2010.

13. Nadimin.2007. Buku Pedoman Pelaksanaan Edukasi gizi Gizi di Provinsi Sulawesi Selatan. Dinkes Prop. Sulsel, Makassar.

14. NIDDK, 2011.National Diabetes Statistics 2011. [online].(diupload pada tahun 2011). http://diabetes.niddk.nih.gov/DM/PUBS/statistics. [diakses pada tanggal 3 Desember 2011].

15. Notoatmodjo S, 2003. Ilmu Kesehatan Masyarakat, Cetakan Pertama. Jakarta: Rineka Cipta.

16. -----------, 2007. Promosi Kesehatan dan IImu Perilaku. Jakarta: Rineka Cipta

17. Puspita, Ira Arta, 2010. Gambaran Karakteristik Dan Penatalaksanaan Pasien Diabetes Melitus Rawat Jalan Di Puskesmas Balangnipa Kab. Sinjai Tahun

18. Riskesdas. 2013. Laporan Nasional 2013. Badan Penelitian dan Pengembangan Kesehatan Departemen Kesehatan, Republik Indonesia, Jakarta.

19. Rusimah, 2011. Hubungan Tingkat Pendidikan Dan Pengetahuan Gizi Dengan Kepatuhan Diet Pada Penderita Diabetes Mellitus (Diabetisi) Di Ruang Rawat InapRsud Dr.H.Moch Ansari Saleh Banjarmasin Tahun 2010. Skripsi Sarjana. Program Studi S1 Gizi, Sekolah Tinggi Ilmu Kesehatan Husada Borneo Banjarbaru, Banjarbaru.

20. Sediaoetama, Prof. DR. Achmad Djaeni., 1987. Ilmu Gizi Jilid 1. Jakarta: Dian Rakyat.

21. Shahab, Alwi, 2006 .Diagnosis Dan PenatalaksanaanDiabetes Melitus(Disarikan Dari Konsensus Pengelolaan Diabetes Melitus Di Indonesia : Perkeni 2006).Subbagian Endokrinologi Metabolik, Bagian Ilmu Penyakit Dalam, Fk Unsri/ Rsmh Palembang, Palembang.

22. Suhl, Emmy MS, RD, LD, CDE, and Patricia Bonsignore, MS, RN, CDE , 2006. Diabetes SelfManagement Education for Older Adults: General Principles and Practical Application, Diabetes Spectrum Volume 19, Number 4, 2006, 234-240.

23. Sukraniti DP, IW Ambartana, 2011. Pengaruh konseling gizi terhadap perubahan kadar gula darah berdasarkan pengetahuan dan kepatuhan diet penderita diabetes mellitus, Jurnal IImu Gizi Volume 2 Nomor 2.

24. Suyono, S. dkk., 2011. Kecenderungan Peningkatan Pasien Diabetes Melitus. Jakarta: FKUI

25. Soegondo, S, Soewondo, P, Subekti, I (editor)., 2007. Penatalaksanaan Diabetes Terpadu : Sebagai panduan penatalaksanaan diabetes mellitus bagi dokter maupun educator. Cetakan ke6. Jakarta: Balai Penerbit FKUI.

26. Soetrisno, dkk., 2005. Buku pintar kesehatan. Jakarta: Ladang Pustaka dan Inti Media.

27. Tjeyan, Suryadi R.M, 2007.Risiko Penyakit Diabetes Mellitus Tipe 2 Di Kalangan Peminum Kopi Di Kotamadya Palembang Tahun 2006-2007.Department Of Public Health And Community Medicine, Medical Faculty, Sriwijaya University, Palembang 30126, Indonesia.Makara, Kesehatan, Vol. 11, No. 2, Desember 2007: 54-60 Hal 54.

28. Wakhidiyah dan Intan Zainafree. 2010. Hubungan Antara Tingkat Pengetahuan, Sikap Dan Keikutsertaan Penyuluhan Gizi Dengan Perilaku Diit Pada Pasien Diabetes Melitus Tipe li Di Klinik Diabetes Melitus Rsj. Prof. Dr Soeroyo Magelang, Kemas - Volume 6/ No. 1 / Juli Desember 2010 [92] Hal 90-98.

29. Waspadji, Sarwono dkk., 2007. Penatalaksanaan Diet Diabetes Melitus. Jakarta: FKUI. 
http://jurnal.csdforum.com/index.php/ghs

30. Witasari, Ucik, dkk. 2009. Hubungan Tingkat Pengetahuan, Asupan Karbohidrat Dan Serat Dengan Pengendalian Kadar Glukosa Darah Pada Penderita Diabetes Melitus Tipe 2. Dalam Jurnal Penelitian Sains \& Teknologi, Vol. 10, No. 2, 2009: [131] Hal $130-138$. Fakultas IImu Kesehatan, Universitas Muhammadiyah, Surakarta.

31. Yanti, dkk. 2008. Faktor-faktor Resiko Kejadian Penyakit Jantung Koroner pada Penderita Diabetes Mellitus Tipe 2 (Studi Kasus di RSUP Dr. Kariadi Semarang): Semarang. 